\title{
PENGARUH KEPEMIMPINAN, BUDAYA ORGANISASI DAN DISIPLIN KERJA TERHADAP KINERJA PEGAWAI DI BADAN KEPEGAWAIAN DAERAH KABUPATEN LABUHANBATU SELATAN
}

\author{
${ }^{1}$ Muhammad Robiq Muhazir, ${ }^{2}$ Waldy Depuansyah Harahap, ${ }_{5}^{3}$ Muhammad Zul Indra, ${ }_{5}^{4}$ Norman Hadiyanto, \\ ${ }^{5}$ Fakhrurrazi Salim \\ 1,2,3,4,5 Universitas Islam Sumatera Utara \\ ${ }^{1}$ mhd.robiq@gmail.com, ${ }^{2}$ waldy.depuansyah@gmail.com, ${ }^{3}$ zul.indra@gmail.com, ${ }_{5}^{4}$ norman.hadiyanto@gmail.com, \\ ${ }^{5}$ fakhrurazi.salim@gmail.com
}

\begin{abstract}
Problem of this study how influence of leadership on performance. How influence of organization culture on performance. How influence of job dicipline on performance. How influence leadership, organization culture and job dicipline on performance. The purpose of this study to determine and analyze the effect of leadership on performance. Determine and analyze the effect of organization culture on performance. Determine and analyze the effect of job dicipline on performance. Determine and analyze the effect of leadership, organization culture and job dicipline on performance. Sample in the study is 34 employees. Data analysis techniques used in this study is descriptive analyze and multiple linear regression analysis. The results of the study indicate leadership variable has a positive and significant effect on performance. organization culture variable has a positive and significant effect on performance. job dicipline variable has a positive and significant effect on performance. Leadership, organization culture and job dicipline variable has a positive and significant effect on performance.
\end{abstract}

Keywords : Leadership, Organization culture, Job dicipline, Performance.

ABSTRAK : Rumusan masalah dalam penelitian ini adalah apakah ada pengaruh kepemimpinan terhadap kinerja. Apakah ada pengaruh budaya organisasi terhadap kinerja. Apakah ada pengaruh disiplin kerja terhadap kinerja. Apakah ada pengaruh kepemimpinan, budaya organisasi dan disiplin kerja terhadap kinerja. Tujuan penelitian ini adalah untuk mengetahui dan menganalisis pengaruh kepemimpinan terhadap kinerja. Untuk mengetahui dan menganalisis pengaruh budaya organisasi terhadap kinerja. Untuk mengetahui dan menganalisis pengaruh disiplin kerja terhadap kinerja. Untuk mengetahui dan menganalisis pengaruh kepemimpinan, budaya organisasi dan disiplin kerja terhadap kinerja. Sampel dalam penelitian ini berjumlah 34 orang pegawai. Teknik analisis data yang digunakan dalam penelitian ini adalah analisis deskriptif dan analisis regresi linier berganda. Hasil penelitian ini menjelaskan bahwa variabel kepemimpinan berpengaruh positif dan signifikan terhadap kinerja. Variabel budaya organisasi berpengaruh positif dan signifikan terhadap kinerja. Variabel disiplin kerja berpengaruh positif dan signifikan terhadap kinerja. Variabel kepemimpinan, budaya organisasi, dan disiplin kerja berpengaruh positif dan signifikan terhadap kinerja.

\section{Kata kunci : Kepemimpinan, Budaya organisasi, Disiplin kerja, Kinerja}

\section{Pendahuluan}

Perkembangan ilmu pengetahuan dan teknologi yang sangat pesat ternyata membawa perubahan yang mendasar pada sendi-sendi kehidupan manusia. Perubahan-perubahan tersebut membawa dampak pada setiap individu untuk meningkatkan kinerja masing-masing. Masalah sumber daya manusia secara historis dapat ditinjau dari perkembangannya sejak dulu.
Bahkan masalah sumber daya manusia yang kelihatannya hanya merupakan masalah intern dari suatu organisasi, sesungguhnya mempunyai hubungan yang erat dengan sendi kehidupan manusia dan masyarakat yang telah menimbulkan berbagai konsepsi tentang sumber daya manusia dan statusnya dalam masyarakat di mana itu berada. Salah satu masalah nasional yang dihadapi oleh bangsa Indonesia saat ini 
adalah penanganan terhadap rendahnya kualitas sumber daya manusia. Jumlah sumber daya manusia di Indonesia yang besar, apabila dapat didayagunakan secara efektif dan efisien akan bermanfaat untuk menunjang laju pembangunan nasional yang berkelanjutan. Agar dalam masyarakat tersedia sumber daya manusia yang handal diperlukan pendidikan yang berkualitas, penyediaan berbagai fasilitas sosial dan lapangan pekerjaan yang memadai. Tantangan utama yang sesungguhnya adalah bagaimana dapat menciptakan sumber daya manusia yang dapat menghasilkan kinerja optimal untuk mencapai tujuan suatu organisasi.

Penilaian terhadap kinerja Aparatur Sipil Negara (ASN) menjadi sangat penting atau dengan kata lain memiliki nilai yang amat strategis. Informasi mengenai kinerja ASN dan faktor-faktor yang ikut berpengaruh terhadap kinerja ASN sangat penting untuk diketahui, sehingga pengukuran kinerja ASN hendaknya dapat diterjemahkan sebagai suatu kegiatan evaluasi untuk menilai atau melihat keberhasilan dan kegagalan pelaksanaan tugas dan fungsi yang dibebankan kepadanya. Oleh karena itu evaluasi kinerja merupakan analisis interpretasi keberhasilan dan kegagalan pencapaian kinerja. Salah satu ahli yang berpendapat tentang kegagalan Pemerintah, Osborne dan Gaebler (1992) yang dikutip oleh Hendriani dan Artati (2014:12) menyatakan bahwa kegagalan utama pemerintah saat ini adalah karena kelemahan manajemennya, bukan pada apa yang dikerjakan pemerintah, melainkan bagaimana caranya pemerintah mengerjakannya. Menurut Hendriani dan Artati (2014:13), bahwa dalam suatu organisasi perlu adanya pemisahan antara manajemen puncak dan operasional, sehingga memungkinkan manajemen puncak mengfokuskan konsentrasi pada pengambilan keputusan dan pengarahan. Sedangkan kegiatan operasional sebaiknya dijalankan oleh staf sendiri, dimana masing-masing memiliki misi, sasaran, ruang lingkup, tindakan serta otonominya sendiri. Upaya mengarahkan, membutuhkan orang yang mampu melihat seluruh visi dan peluang serta mampu menyeimbangkan antar berbagai tuntutan yang saling bersaing untuk mendapatkan sumber daya. Hal tersebut membutuhkan personil yang bersungguhsungguh fokus pada visi , misi dan melaksanakannya dengan baik.
Penelitian ini dilakukan pada Badan Kepegawaian Daerah Kabupaten Labuhanbatu Selatan, dengan salah satu faktor yang mempengaruhi kinerja pegawai adalah kepemimpinan. Didalam suatu organisasi fenomena tentang kepemimpinan adalah halhal yang terdapat dalam setiap komunitas, karena dimana manusia berinteraksi maka disana timbul fenomena kepemimpinan, mulai dari interaksi dalam kelompok yang paling primitif sampai ke yang paling maju, mulai dari kelompok yang paling terkecil sampai ke organisasi yang paling besar. Kepemimpinan biasanya ditentukan oleh sifat, kualitas, dan perilaku pemimpin. Faktor kepemimpinan dalam suatu organisasi menjadi sangat penting manakala individu/anggota organisasi memiliki dinamika yang tinggi dalam aktivitasnya disamping perubahan terus menerus yang didorong oleh kemajuan teknologi, kata kunci dari fenomena ini adalah kemampuan untuk mempengaruhi anggota organisasi sehingga mereka dengan segala kesungguhan berusaha untuk mencapai tujuan organisasi yang telah ditetapkan sebelumnya. Suatu organisasi akan berhasil atau bahkan gagal sebagian besar ditentukan oleh faktor kepemimpinan. Karena rendahnya kinerja birokrasi publik sangat dipengaruhi oleh budaya paternalisme yang masih sangat kuat, yang cenderung mendorong pejabat birokrasi untuk lebih berorientasi pada kekuasaan dari pada pelayanan, menempatkan dirinya sebagai penguasa dan memperlakukan para pengguna jasa sebagai obyek pelayanan yang membutuhkan bantuannya. Disamping itu, rendahnya kinerja juga disebabkan oleh sistem pembagian kekuasaan yang cenderung memusat pada pimpinan. Hasil penelitian terdahulu dari Fauzi (2013) menyatakan bahwa kepemimpinan berpengaruh positif dan signifikan terhadap kinerja. Hasil penelitian Osabiya Babatunde, Ikenga Emem (2015) menyatakan gaya kepemimpinan berpengaruh positif dan signifikan terhadap kinerja. Hasil penelitian dari Sami'an dan Estu Aprilian N.W, (2013) juga menyatakan bahwa kepemimpinan berpengaruh positif dan signifikan terhadap kinerja. Sementara hasil penelitian dari Rahayu Saputri, Nur Rahmah Andayani, (2018) menyatakan kepemimpinan berpengaruh negatif dan tidak signifikan terhadap kinerja. Dari hasil penelitian terdahulu tersebut jelas adanya research gap, sehingga menarik peneliti untuk 
melakukan penelitian lanjutan di Badan Kepegawaian Daerah Kabupaten Labuhanbatu Selatan

Penelitian pada organisasi yang memusatkan perhatian pada aspek-aspek manusia tampaknya mulai berkembang dan diminati beberapa tahun terakhir ini, sehingga muncul konsep-konsep pemikiran mengenai organisasi yang didorong oleh berbagai keberhasilan organisasi dalam mengembangkan unsur manusia dalam perancangan dan penataan organisasi. Tidak hanya sebagai salah satu bagian penting dalam studi organisasi, tetapi konsep budaya dipergunakan sebagai metafora untuk menjelaskan perwujudan dan hakekat organisasi. Penggunaannya dalam analisis organisasi, budaya tidak hanya dipandang sebagai sesuatu yang ada dan hidup dalam suatu organisasi, tetapi juga sesuatu yang dipergunakan sebagai landasan pemikiran dalam pemahaman organisasi. Sebagai suatu variabel dalam organisasi, budaya dipelajari sebagai bagian dari sistem organisasi secara keseluruhan. Dalam konteks ini, budaya dilihat sebagai sesuatu yang hidup di suatu organisasi yang mengikat semua anggota organisasi dalam upaya mencapai tujuan bersama. Budaya juga dapat dilihat sebagai bagian dari suatu lingkungan organisasi yang mempengaruhi perilaku dan penampilan (performance) organisasi.

Budaya organisasi merupakan sekumpulan nilai, yang dengan sengaja diambil dan dikembangkan oleh pemilik (founders) untuk dijadikan pegangan dalam bersikap dan bertindak bagi seluruh pegawai. Apabila budaya organisasi bermanfaat bagi pegawai (misalnya, memperhatikan dan berorientasi pada prestasi, keadilan dan sportivitas), maka dapat diharapkan adanya peningkatan kinerja yang lebih baik dari pada sebelumnya. Sebaliknya jika budaya organisasi yang ada bertentangan dengan tujuan, kebutuhan dan motivasi pribadi, kemungkinan yang timbul adalah kinerja pegawai menjadi menurun. Dengan kata lain suatu organisasi ditentukan oleh interaksi antara kebutuhan dengan budaya organisasi yang ada dalam organisasi tersebut. Beberapa penelitian terdahulu menarik kesimpulan budaya organisasi merupakan variabel yang dapat mempengaruhi kinerja secara langsung. Akan tetapi masih terdapat kesenjangan penelitian tentang pengaruh budaya organisasi terhadap kinerja. Penelitian terdahulu dari Arifudin et.al
(2018), Jatilaksono (2016), Maskur, (2010), Muchtar Adama (2014), Pranoto (2014), Soepardjo et.al (2014), kesemuanya menarik kesimpulan bahwa budaya organisasi berpengaruh signifikan terhadap kinerja. Sementara hasil penelitian yang dilakukan oleh Wulan Sari Girsang (2019) menunjukkan bahwa budaya organisasi berpengaruh negatif dan tidak signifikan terhadap kinerja. Adanya kesenjangan dari penelitian terdahulu tersebut menarik peneliti untuk melakukan penelitian lanjutan terhadap pegawai di Badan Kepegawaian Daerah Kabupaten Labuhanbatu Selatan.

Disiplin kerja pegawai di Badan Kepegawaian Daerah Kabupaten Labuhanbatu Selatan merupakan satu fungsi dari manajemen sumber daya manusia karena dengan kondisi ajemen sumber daya manusia karena dengan kondisi yang penuh dengan disiplin, pegawai dapat diharapkan menjadi tonggak dasar yang tangguh pada suatu organisasi untuk mencapai tujuan. Dengan adanya pegawai yang berdisiplin kerja, dimana mereka mematuhi segala aturan dalam organisasi, kondisi tersebut akan memberikan dukungan positif kepada pencapaian tujuan organisasi yang pada umumnya dikendalikan oleh manusia dengan aneka ragam disiplin ilmu, keterampilan dan tanggung jawab. Peraturan disiplin kerja dalam suatu organisasi/instansi sudah berjalan sebagaimana mestinya atau belum, dapat dilihat dari pegawai datang ke kantor tepat waktu, mereka selalu berpakaian seragam di tempat bekerja, mereka menggunakan bahan dan perlengkapan dengan hati-hati dan menurut peraturan, menghasilkan jumlah dan kualitas pekerjaan yang menurut standar, apabila mengikuti cara kerja yang ditentukan kantor, dan mereka melakukan pekerjaan dengan semangat yang baik. Penelitian terdahulu yang telah membuktikan bahwa disiplin kerja yang baik dari pegawai dapat meningkatkan kinerja, diantaranya hasil penelitian dari Dedi Hadian (2018); Flavia et.al (2017); Muhd. Darwis Damir (2016); Regina Aditya Reza (2010); dan Sarwani (2017).

\subsection{Rumusan Masalah}

Berdasarkan batasan masalah yang telah diidentifikasi maka peneliti merumuskan masalah yang berkaitan dengan penelitian ini adalah : 
1) Apakah ada pengaruh kepemimpinan terhadap kinerja pegawai di Badan Kepegawaian Daerah Kabupaten Labuhanbatu Selatan.

2) Apakah ada pengaruh budaya organisasi terhadap kinerja pegawai di Badan Kepegawaian Daerah Kabupaten Labuhanbatu Selatan.

3) Apakah ada pengaruh disiplin kerja terhadap kinerja pegawai di Badan Kepegawaian Daerah Kabupaten Labuhanbatu Selatan.

4) Apakah ada pengaruh kepemimpinan, budaya organisasi dan disiplin kerja terhadap kinerja pegawai di Badan Kepegawaian Daerah Kabupaten Labuhanbatu Selatan.

\subsection{Batasan Masalah}

Berdasarkan uraian di atas, banyak faktor yang berpengaruh pada variabel kinerja pegawai di Kantor Otoritas Pelabuhan Utama Belawan, sehingga dalam penelitian ini peneliti membatasi kepada variabel independen kepemimpinan, budaya organisasi dan kinerja pegawai.

\subsection{Hipotesis}

Berdasarkan pada kerangka konseptual di atas, maka hipotesis dalam penelitian ini adalah

1) Ada pengaruh kepemimpinan terhadap kinerja pegawai di Badan Kepegawaian Daerah Kabupaten Labuhanbatu Selatan.

2) Ada pengaruh budaya organisasi terhadap kinerja pegawai di Badan Kepegawaian Daerah Kabupaten Labuhanbatu Selatan.

3) Ada pengaruh disiplin kerja terhadap kinerja pegawai di Badan Kepegawaian Daerah Kabupaten Labuhanbatu Selatan.

4) Ada pengaruh kepemimpinan, budaya organisasi dan disiplin kerja terhadap kinerja pegawai di Badan Kepegawaian Daerah Kabupaten Labuhanbatu Selatan.

\subsection{Tujuan Penelitian}

Tujuan dari penelitian ini adalah :

1) Untuk menganalisis pengaruh kepemimpinan terhadap kinerja pegawai di Badan Kepegawaian Daerah Kabupaten Labuhanbatu Selatan.

2) Untuk menganalisis pengaruh budaya organisasi terhadap kinerja pegawai di Badan Kepegawaian Daerah Kabupaten Labuhanbatu Selatan.

3) Untuk menganalisis pengaruh disiplin kerja terhadap kinerja pegawai di Badan Kepegawaian Daerah Kabupaten Labuhanbatu Selatan.

4) Untuk menganalisis pengaruh kepemimpinan, budaya organisasi dan disiplin kerja terhadap kinerja pegawai di Badan Kepegawaian Daerah Kabupaten Labuhanbatu Selatan.

\section{Metode Penelitian}

\subsection{Populasi}

Menurut Sugiyono (2014:55), populasi adalah wilayah generalisasi yang terdiri atas obyek/subjek yang mempunyai kuantitas dan karakteristik tertentu yang ditetapkan oleh peneliti untuk dipelajari dan kemudian ditarik kesimpulannya. Jadi populasi bukan hanya orang tetapi juga benda-benda alam yang lain. Populasi juga bukan sekedar jumlah yang ada pada objek/subjek yang dipelajari, tetapi meliputi seluruh karakteristik, sifat yang dimiliki objek/subjek itu. Dari pengertian tersebut, maka dapat disimpulkan bahwa populasi merupakan subjek penelitian dimana individu yang akan dikenai perilaku atau dapat dikatakan sebagai keseluruhan objek penelitian yang akan diteliti. Maka populasi dalam penelitian ini adalah para pegawai Badan Kepegawaian Daerah Kabupaten Labuhanbatu Selatan yang berjumlah 34 orang, dimana Kepala Badan dan peneliti tidak dihitung sebagai populasi.

Tabel 1. Kerangka populasi pegawai

\begin{tabular}{|c|l|c|}
\hline No & \multicolumn{1}{|c|}{ Keterangan } & $\begin{array}{c}\text { Jumlah } \\
\text { (Orang) }\end{array}$ \\
\hline 1 & Sekretariat & 10 \\
\hline 2 & Bidang Program Pendataan Kepegawaian & 8 \\
\hline 3 & Bidang Mutasi & 9 \\
\hline 4 & Bidang Pengembangan dan Pemberdayaan Pegawai & 7 \\
\hline \multicolumn{2}{|c|}{ Jumlah } & 34 \\
\hline
\end{tabular}

Sumber : BKD Kabupaten Labusel, 2021 


\subsection{Sampel}

Menurut Sugiyono (2011:93), sampel adalah elemen-elemen populasi yang dipilih atas dasar kemampuan mewakilinya. Untuk menjadi pedoman jika subjeknya atau populasinya kurang dari 100, maka lebih baik diambil semua sebagai sampel, sehingga penelitiannya merupakan penelitian populasi.
Selanjutnya jika jumlah subjeknya atau populasinya besar atau lebih dari 100, maka dapat diambil persentasenya. Dengan menggunakan teknik penarikan sampel yaitu total sampling atau metode sensus, maka sampel dalam penelitian ini berjumlah 34 orang pegawai di Badan Kepegawaian Daerah Kabupaten Labuhanbatu Selatan.

Tabel 2. Kerangka sampel pegawai

\begin{tabular}{|c|l|c|}
\hline No & \multicolumn{1}{|c|}{ Keterangan } & $\begin{array}{c}\text { Jumlah } \\
\text { (Orang) }\end{array}$ \\
\hline 1 & Sekretariat & 10 \\
\hline 2 & Bidang Program Pendataan Kepegawaian & 8 \\
\hline 3 & Bidang Mutasi & 9 \\
\hline 4 & Bidang Pengembangan dan Pemberdayaan Pegawai & 7 \\
\hline \multicolumn{2}{|c|}{ Jumlah } & 34 \\
\hline
\end{tabular}

Sumber : BKD Kabupaten Labusel, 2021

\subsection{Uji Normalitas}

Menurut Duwi Priyatno (2012:144) pengertian dari uji normalitas adalah untuk menguji apakah nilai residual yang dihasilkan dari regresi terdistribusi secara normal atau tidak. Model regresi yang baik adalah yang memiliki nilai residual yang terdistribusi normal. Untuk mengetahui bentuk distribusi data, bisa dilakukan dengan grafik distribusi dan analisis statistik. Pengujian dengan distribusi dilakukan dengan melihat grafik histogram yang membandingkan antara dua observasi dengan distribusi yang mendekati distribusi normal. Distribusi normal akan membentuk satu garis lurus diagonal dan ploating data residual akan dibandingkan dengan garis diagonal. Jika distribusi atau residual normal, maka garis yang menggambarkan data yang sesungguhnya akan mengikuti garis diagonalnya. Uji normalitas dengan grafik dapat dilakukan dengan program SPSS dengan analisis grafik Normal Probability Plot

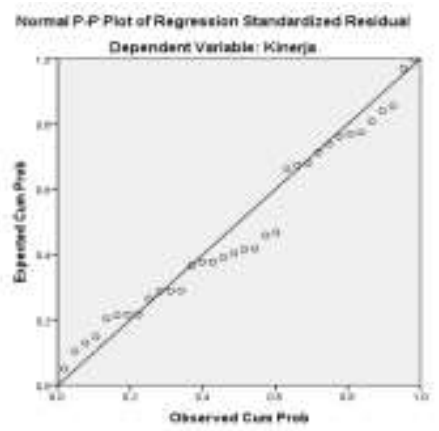

Gambar 1. Uji normalitas data
Berdasarkan gambar 1, diatas terlihat titiktitik dari ploating data residual berada di garis diagonal, hal ini dapat disimpulkan data yang diuji berdistribusi normal.

\subsection{Uji Multikolinieritas}

Salah satu asumsi dari model regresi linier bahwa tidak terjadi korelasi yang signifikan antara variabel bebasnya. Untuk menguji hal tersebut maka diperlukan suatu uji yang disebut uji multikolinieritas. Menurut Duwi Priyatno (2012:151) pengertian multikolinieritas adalah keadaan di mana pada model regresi ditemukan adanya korelasi yang sempurna atau mendekati sempurna antar variabel independen. Pada regresi yang baik seharusnya tidak terjadi korelasi yang sempurna atau mendekati sempurna diantara variabel bebas. Uji multikolinieritas adalah untuk melihat ada atau tidaknya korelasi yang tinggi antara variabelvariabel bebasnya, maka hubungan antara variabel bebas terhadap variabel terikatnya menjadi terganggu. Jika terdapat korelasi yang kuat dimana sesama variabel independen maka konsekuensinya adalah :

a. Koefisien-koefisien regresi menjadi tidak dapat ditaksir

b. Nilai standar error setiap koefisien regresi menjadi tidak terhingga.

Dengan demikian, semakin besar korelasi diantara sesama variabel independen maka tingkat kesalahan dari koefisien regresi semakin besar yang dapat mengakibatkan standar error semakin besar pula. Cara yang digunakan untuk mendeteksi ada tidaknya multikolinieritas adalah dengan melihat besarnya nilai Variance Inflation Factor (VIF). 
Jika VIF dibawah 10 dan Tolerance Value diatas 0,1 maka tidak terjadi multikolinieritas.

Tabel 3. Uji multikolinieritas

\begin{tabular}{|l|c|c|}
\hline \multirow{2}{*}{\multicolumn{1}{|c|}{ Variabel }} & \multicolumn{2}{c|}{ Collinearity Statistics } \\
\cline { 2 - 3 } & Tolerance & VIF \\
\hline Kepemimpinan & 0.912 & 1.096 \\
\hline Budaya organisasi & 0.971 & 1.030 \\
\hline Disiplin kerja & 0.888 & 1.127 \\
\hline
\end{tabular}

a. Dependent Variable : Kinerja

Hasil pengolahan data, 2021

Berdasarkan Tabel 3 diatas diperoleh nilai Tolerance Value diatas 0.1 yaitu $0.912,0.917$, dan 0.888 , hal ini menunjukan adanya korelasi yang cukup tinggi/kuat antara sesama variabel bebas dan nilai Variance Inflantion Factorrs (VIF) sebesar 1.096, 1.030, dan 1.127, dimana nilai VIF dari ketiga varibel bebas lebih kecil dari 10 dan dapat disimpulkan tidak terdapat multikolinieritas diantara ketiga variabel bebas yang diuji dalam penelitian ini.

\subsection{Uji Autokorelasi}

Uji autokorelasi merupakan pengujian dimana variabel dependen tidak berkorelasi dengan nilai variabel itu sendiri, baik nilai periode sebelumnya maupun nilai periode sesudahnya. Menurut Duwi Priyatno
(2012:172) pengertian dari autokorelasi adalah keadaan di mana pada model regresi ada korelasi antara residual pada periode tertentu $t$ dengan residual pada periode sebelumnya ( $\mathrm{t}-1)$, model regresi yang baik adalah yang tidak terdapat masalah autokorelasi. Metode pengujian menggunakan uji Durbin-Watson (DW-test). Salah satu ukuran dalam menentukan ada tidaknya masalah autokorelasi dengan uji Durbin-Watson (DW) dengan ketentuan sebagai berikut :

Terjadi autokorelasi positif jika nilai DW dibawah -2 atau DW $<-2$

Tidak terjadi autokorelasi jika nilai DW diantara -2 dan +2 atau $-2<$ DW $<+2$

Terjadi autokorelasi negatif jika nilai DW di atas 2 atau DW $>2$.

Tabel 4. Uji Autokorelasi

\begin{tabular}{|c|c|c|c|c|c|c|}
\hline \multirow[b]{2}{*}{ Model } & \multicolumn{5}{|c|}{ Change Statistics } & \multirow{2}{*}{$\begin{array}{l}\text { Durbin- } \\
\text { Watson }\end{array}$} \\
\hline & $\begin{array}{c}R \text { Square } \\
\text { Change }\end{array}$ & F Change & df1 & df2 & $\begin{array}{l}\text { Sig. F } \\
\text { Change }\end{array}$ & \\
\hline 1 & .614 & 15.914 & 3 & 30 & .000 & 2.096 \\
\hline
\end{tabular}

Berdasarkan Tabel 5.17 di atas diperoleh nilai Durbin-Watson (DW) sebesar 2.096, nilai ini berada pada kisaran $-2<\mathrm{DW}<+2$, maka dapat disimpulkan bahwa tidak terjadi autokorelasi pada model regresi dalam penelitian ini.

\subsection{Uji Heteroskedastisitas}

Uji heteroskedastisitas bertujuan untuk menguji apakah dalam model regresi terjadi ketidaksamaan variance dari residual satu pengamatan ke pengamatan yang lainnya. Gejala variance yang tidak sama ini disebut dengan heteroskedastisitas, sedangkan adanya gejala residual yang sama dari satu pengamatan ke pengamatan lain disebut dengan homokedastisitas. Menurut Duwi Priyatno (2012:158) pengertian dari heteroskedastisitas adalah dimana dalam model regresi tejadi ketidaksamaan varian dari residual pada suatu pengamatan ke pengamatan yang lain. Model regresi yang baik adalah tidak terjadi heteroskedastisitas. Berbagai macam uji heteroskedastisitas yaitu dengan uji glejser, melihat pola titik-titik pada scatterplots regresi, atau uji koefisien korelasi spearman's.

Uji heteroskedastisitas dapat dilakukan dengan menggunakan grafik scatterplot antara nilai variabel terikat (ZSPRED) dengan residualnya (SRESID), dimana sumbu $X$ adalah yang diprediksi dan sumbu $\mathrm{Y}$ adalah residual. Dasar pengambilan keputusan yang dapat diambil adalah sebagai berikut :

a. Jika pola tertentu seperti titik-titik yang ada membentuk suatu pola yang teratur (bergelombang, melebar kemudian menyempit) maka telah terjadi heteroskedastisitas. 
b. Jika tidak ada yang jelas serta titik-titik menyebar diatas dan dibawah angka nol pada sumbu Y maka tidak terjadi heteroskedastisitas

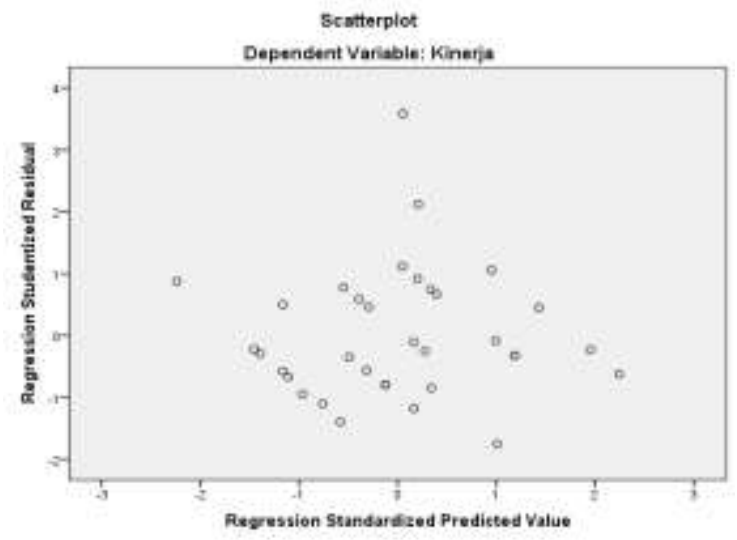

Gambar 2. Uji heteroskedastisitas
Berdasarkan gambar 2, diatas, menunjukkan titik-titik yang menyebar, sehingga dapat disimpulkan tidak terjadi heteroskedastisitas di data penelitian ini.

\section{Uji Hipotesis}

Dalam uji hipotesis ini peneliti akan melihat model persamaan regresi berganda dan akan menguji kebenaran hipotesis baik itu secara partial atau sendiri-sendiri, maupun secara simultan atau bersama-sama, dan untuk memudahkan peneliti dalam pengolahan data, maka digunakan Program Statistical Product and Service Solutions versi 22.00.

\subsection{Analisis Regresi Linier Berganda.}

Analisis regresi linier berganda dalam penelitian ini dapat dilihat dari persamaan regresinya, dan dari hasil pengolahan data diperoleh hasil berikut ini :

Tabel 5. Analisis regresi linier berganda

\begin{tabular}{|l|r|r|r|r|r|}
\hline \multirow{2}{*}{ Model } & \multicolumn{2}{|c|}{$\begin{array}{c}\text { Unstandardized } \\
\text { Coefficients }\end{array}$} & $\begin{array}{c}\text { Standardized } \\
\text { Coefficients } \\
\text { Beta }\end{array}$ & \multirow{2}{*}{$\mathrm{t}$} & \multirow{2}{*}{ Sig. } \\
\cline { 2 - 3 } & \multicolumn{1}{|c|}{$\mathrm{B}$} & Std. Error & & \\
\hline (Constant) & 1.273 & 7.059 & & .180 & .858 \\
\hline Kepemimpinan & .542 & .117 & .549 & 4.627 & .000 \\
\hline Budaya organisasi & .226 & .095 & .274 & 2.379 & .024 \\
\hline Disiplin kerja & .273 & .085 & .388 & 3.219 & .003 \\
\hline
\end{tabular}

Hasil pengolahan data, 2021

Berdasarkan Tabel 5. diatas dapat dibuat persamaan regresi dalam penelitian ini sebagai berikut:

$$
\mathrm{Y}=1.273+0.542 \mathrm{X}_{1}+0.226 \mathrm{X}_{2}+0.273 \mathrm{X}_{3}
$$

Dari persamaan regresi linier berganda di atas dapat dijelaskan :

1) Nilai kinerja pegawai di Badan Kepegawaian Daerah Kabupaten Labuhanbatu Selatan sebesar 1.273, yang mana nilai dari variabel dari variabel kepemimpinan, budaya organisasi dan disiplin kerja diabaikan.

2) Nilai koefisien regresi $X_{1}$ (kepemimpinan) mempunyai nilai positif yaitu 0.542 , hal ini menunjukkan bahwa variabel kepemimpinan mempunyai pengaruh yang searah dan positif terhadap kinerja pegawai di Badan Kepegawaian Daerah Kabupaten Labuhanbatu Selatan.

3) Nilai koefisien regresi $X_{2}$ (budaya organisasi) mempunyai nilai positif yaitu 0.226 , hal ini menunjukkan bahwa variabel budaya kerja mempunyai pengaruh yang searah dan positif terhadap kinerja pegawai di Badan Kepegawaian Daerah Kabupaten Labuhanbatu Selatan.

4) Nilai koefisien regresi $X_{3}$ (disiplin kerja) mempunyai nilai positif yaitu 0.273 , hal ini menunjukkan bahwa variabel disiplin kerja mempunyai pengaruh yang searah dan positif terhadap kinerja pegawai di Badan Kepegawaian Daerah Kabupaten Labuhanbatu Selatan.

\subsection{Pengaruh Kepemimpinan Terhadap Kinerja Pegawai di Badan Kepegawaian Daerah Kabupaten Labuhanbatu Selatan.}

Untuk mengetahui pengaruh kepemimpinan terhadap kinerja pegawai di Badan Kepegawaian Daerah Kabupaten Labuhanbatu Selatan digunakan uji-t, sedangkan untuk melihat besarnya pengaruh digunakan nilai Beta atau Standardized Coefficient Beta. 
Tabel. 6. Pengaruh kepemimpinan terhadap kinerja

\begin{tabular}{|l|r|r|r|r|r|}
\hline \multirow{2}{*}{ Model } & \multicolumn{2}{|c|}{$\begin{array}{c}\text { Unstandardized } \\
\text { Coefficients }\end{array}$} & \multirow{2}{*}{$\begin{array}{c}\text { Standardized } \\
\text { Coefficients } \\
\text { Beta }\end{array}$} & \multirow{2}{*}{$\mathrm{t}$} & \multirow{2}{*}{ Sig. } \\
\cline { 2 - 3 } & \multicolumn{1}{|c|}{$\mathrm{B}$} & \multicolumn{1}{|c|}{ Std. Error } & & \\
\hline (Constant) & 1.273 & 7.059 & & .180 & .858 \\
\hline Kepemimpinan & .542 & .117 & .549 & 4.627 & .000 \\
\hline
\end{tabular}

a. Dependent Variable : Kinerja

Hasil pengolahan data, 2021

Dari Tabel 6. diatas diperoleh nilai $\mathrm{t}_{\text {hitung }}$ sebesar 4.627. Penelitian ini menggunakan taraf signifikansi $(\alpha: 0.05)$ dan Derajat Kebebasan (DK) dengan ketentuan DK $=\mathrm{n}-2$, atau $34-2$ $=32$. Dengan ketentuan tersebut, diperoleh nilai $\mathrm{t}_{\text {tabel }}$ sebesar 2.036. Dengan kriteria hipotesis sebagai berikut :

Jika $t_{\text {hitung }}>t_{\text {tabel }}$, maka $\mathrm{H}_{0}$ ditolak dan $\mathrm{H}_{1}$ diterima.

Jika $\mathrm{t}_{\text {hitung }}<\mathrm{t}_{\text {tabel }}$, maka $\mathrm{H}_{0}$ diterima dan $\mathrm{H}_{1}$ ditolak.

Dari hasil pengolahan data diperoleh nilai $t_{\text {hitung }}>t_{\text {tabel }}(4.627>2.036)$ dan nilai signifikasi lebih kecil dari nilai $\alpha: 0.05$ yaitu $0.000<0.05$, sehingga $\mathrm{H}_{0}$ ditolak dan $\mathrm{H}_{1}$ diterima. Artinya variabel kepemimpinan secara partial berpengaruh positif dan signifikan terhadap kinerja pegawai di Badan Kepegawaian Daerah Kabupaten Labuhanbatu Selatan. Besarnya pengaruh variabel kepemimpinan terhadap kinerja pegawai di Badan Kepegawaian Daerah Kabupaten Labuhanbatu Selatan sebesar 0.549 atau $54.90 \%$.

\subsection{Pengaruh Budaya Organisasi Terhadap Kinerja Pegawai di Badan Kepegawaian Daerah Kabupaten Labuhanbatu Selatan.}

Untuk mengetahui pengaruh budaya organisasi terhadap kinerja pegawai di Badan Kepegawaian Daerah Kabupaten Labuhanbatu Selatan digunakan uji-t, sedangkan untuk melihat besarnya pengaruh digunakan nilai Beta atau Standardized Coefficient Beta.

Tabel. 7. Pengaruh budaya organisasi terhadap kinerja

\begin{tabular}{|l|r|r|r|r|r|}
\hline \multirow{2}{*}{ Model } & \multicolumn{2}{|c|}{$\begin{array}{c}\text { Unstandardized } \\
\text { Coefficients }\end{array}$} & \multirow{2}{*}{$\begin{array}{c}\text { Standardized } \\
\text { Coefficients } \\
\text { Beta }\end{array}$} & \multirow{2}{*}{$\mathrm{t}$} & \multirow{2}{*}{ Sig. } \\
\cline { 2 - 3 } & \multicolumn{1}{|c|}{$\mathrm{B}$} & \multicolumn{1}{|c|}{ Std. Error } & & \\
\hline (Constant $)$ & 1.273 & 7.059 & & .180 & .858 \\
\hline Budaya organisasi & .226 & .095 & .274 & 2.379 & .024 \\
\hline
\end{tabular}

a. Dependent Variable : Kinerja

Hasil pengolahan data, 2021

Dari Tabel 7. diatas diperoleh nilai $\mathrm{t}_{\text {hitung }}$ sebesar 2.379. Penelitian ini menggunakan taraf signifikansi $(\alpha: 0.05)$ dan Derajat Kebebasan (DK) dengan ketentuan DK $=\mathrm{n}-2$, atau $34-2$ $=32$. Dengan ketentuan tersebut, diperoleh nilai $t_{\text {tabel }}$ sebesar 2.036. Dengan kriteria hipotesis sebagai berikut :

Jika $t_{\text {hitung }}>t_{\text {tabel}}$, maka $\mathrm{H}_{0}$ ditolak dan $\mathrm{H}_{1}$ diterima.

Jika $\mathrm{t}_{\text {hitung }}<\mathrm{t}_{\text {tabel }}$, maka $\mathrm{H}_{0}$ diterima dan $\mathrm{H}_{1}$ ditolak.

Dari hasil pengolahan data diperoleh nilai $t_{\text {hitung }}>t_{\text {tabel }}(2.379>2.036)$ dan nilai signifikasi lebih kecil dari nilai $\alpha: 0.05$ yaitu $0.024<0.05$, sehingga $\mathrm{H}_{0}$ ditolak dan $\mathrm{H}_{1}$ diterima. Artinya variabel budaya organisasi secara partial berpengaruh positif dan signifikan terhadap kinerja pegawai di Badan Kepegawaian Daerah Kabupaten Labuhanbatu Selatan. Besarnya pengaruh variabel budaya organisasi terhadap kinerja pegawai di Badan Kepegawaian Daerah Kabupaten Labuhanbatu Selatan sebesar 0.274 atau $27.40 \%$.

\subsection{Pengaruh Disiplin Kerja Terhadap Kinerja Pegawai di Badan Kepegawaian Daerah Kabupaten Labuhanbatu Selatan.}

Untuk mengetahui pengaruh disiplin kerja terhadap kinerja pegawai di Badan Kepegawaian Daerah Kabupaten Labuhanbatu Selatan digunakan uji-t, sedangkan untuk melihat besarnya pengaruh digunakan nilai Beta atau Standardized Coefficient Beta. 
Tabel. 8. Pengaruh disiplin kerja terhadap kinerja

\begin{tabular}{|l|r|r|r|r|r|}
\hline \multirow{2}{*}{ Model } & \multicolumn{2}{|c|}{$\begin{array}{c}\text { Unstandardized } \\
\text { Coefficients }\end{array}$} & \multirow{2}{*}{$\begin{array}{c}\text { Standardized } \\
\text { Coefficients } \\
\text { Beta }\end{array}$} & \multirow{2}{*}{$\mathrm{t}$} & \multirow{2}{*}{ Sig. } \\
\cline { 2 - 3 } & \multicolumn{1}{|c|}{$\mathrm{B}$} & \multicolumn{1}{|c|}{ Std. Error } & & \\
\hline (Constant) & 1.273 & 7.059 & & .180 & .858 \\
\hline Disiplin kerja & .273 & .085 & .388 & 3.219 & .003 \\
\hline
\end{tabular}

a. Dependent Variable : Kinerja

Hasil pengolahan data, 2021

Dari Tabel 8. diatas diperoleh nilai $\mathrm{t}_{\text {hitung }}$ sebesar 3.219. Penelitian ini menggunakan taraf signifikansi $(\alpha: 0.05)$ dan Derajat Kebebasan (DK) dengan ketentuan DK $=\mathrm{n}-2$, atau $34-2$ $=32$. Dengan ketentuan tersebut, diperoleh nilai $t_{\text {tabel }}$ sebesar 2.036. Dengan kriteria hipotesis sebagai berikut :

Jika $t_{\text {hitung }}>t_{\text {tabel }}$, maka $\mathrm{H}_{0}$ ditolak dan $\mathrm{H}_{1}$ diterima.

Jika $t_{\text {hitung }}<\mathrm{t}_{\text {tabel }}$, maka $\mathrm{H}_{0}$ diterima dan $\mathrm{H}_{1}$ ditolak.

Dari hasil pengolahan data diperoleh nilai $t_{\text {hitung }}>t_{\text {tabel }}(3.219>2.036)$ dan nilai signifikasi lebih kecil dari nilai $\alpha: 0.05$ yaitu $0.003<0.05$, sehingga $\mathrm{H}_{0}$ ditolak dan $\mathrm{H}_{1}$ diterima. Artinya variabel disiplin kerja secara partial berpengaruh positif dan signifikan terhadap kinerja pegawai di Badan Kepegawaian Daerah
Kabupaten Labuhanbatu Selatan. Besarnya pengaruh variabel disiplin kerja terhadap kinerja pegawai Badan Kepegawaian Daerah Kabupaten Labuhanbatu Selatan sebesar 0.388 atau $38.80 \%$.

\subsection{Pengaruh Kepemimpinan, Budaya Organisasi dan Disiplin Kerja Terhadap Kinerja Pegawai di Badan Kepegawaian Daerah Kabupaten Labuhanbatu Selatan}

Untuk mengetahui pengaruh kepemimpinan, budaya organisasi dan disiplin kerja terhadap kinerja pegawai Badan Kepegawaian Daerah Kabupaten Labuhanbatu Selatan digunakan ujiF.

Tabel 9. Pengaruh kepemimpinan, budaya organisasi dan disiplin kerja terhadap kinerja

\begin{tabular}{|l|l|r|r|r|r|c|}
\hline \multirow{3}{*}{ Model } & & $\begin{array}{c}\text { Sum of } \\
\text { Squares }\end{array}$ & \multicolumn{1}{c|}{ df } & $\begin{array}{c}\text { Mean } \\
\text { Square }\end{array}$ & \multicolumn{1}{c|}{ F } & Sig. \\
\hline \multirow{4}{*}{1} & Regression & 182.352 & 3 & 60.784 & 15.914 & $.000^{\mathrm{a}}$ \\
\cline { 2 - 7 } & Residual & 114.589 & 30 & 3.820 & & \\
\cline { 2 - 7 } & Total & 296.941 & 33 & & & \\
\hline
\end{tabular}

Dependent Variable : Kinerja

Hasil pengolahan data, 2021

Dari Tabel 9. di atas diperoleh nilai $\mathrm{F}_{\text {hitung }}$ sebesar 15.914. Penelitian ini menggunakan taraf signifikansi $(\alpha: 0.05)$ dan Derajat Kebebasan (DK) dengan ketentuan numerator : jumlah variabel -1 atau $4-1=3$, dan jumlah sampel dikurang 4 atau $34-4=30$. Dengan ketentuan tersebut, diperoleh nilai $\mathrm{F}_{\text {tabel }}$ sebesar 3.330. Dengan kriteria pengujian hipotesis sebagai berikut :

Jika $\mathrm{F}_{\text {hitung }}>\mathrm{F}_{\text {tabel }}$, maka $\mathrm{H}_{0}$ ditolak dan $\mathrm{H}_{1}$ diterima.

Jika $\mathrm{F}_{\text {hitung }}<\mathrm{F}_{\text {tabel }}$, maka $\mathrm{H}_{0}$ diterima dan $\mathrm{H}_{1}$ ditolak.

Dari hasil perhitungan diperoleh nilai $\mathrm{F}_{\text {hitung }}$ $>\mathrm{F}_{\text {tabel }}(15.914>3.330)$ dan nilai signifikasi $0.000<0.05$, sehingga $\mathrm{H}_{0}$ ditolak dan $\mathrm{H}_{1}$ diterima. Artinya variabel kepemimpinan, budaya organisasi dan disiplin kerja secara simultan berpengaruh positif dan signifikan terhadap kinerja pegawai di Badan Kepegawaian Daerah Kabupaten Labuhanbatu Selatan. Dengan demikian model regresi ini sudah layak dan benar dan dapat disimpulkan bahwa variabel kepemimpinan, budaya organisasi dan disiplin kerja berpengaruh terhadap kinerja pegawai di Badan Kepegawaian Daerah Kabupaten Labuhanbatu Selatan.

\subsection{Uji Determinan}

Uji determinan adalah untuk mengetahui seberapa besar pengaruh variabel kepemimpinan, budaya organisasi dan disiplin kerja terhadap kinerja pegawai Badan Kepegawaian Daerah Kabupaten Labuhanbatu Selatan, dan dapat dilihat dari model summary, khususnya nilai Rsquare. 
Tabel 10. Model summary ${ }^{\mathrm{b}}$ pengaruh kepemimpinan, budaya organisasi dan disiplin kerja terhadap

\begin{tabular}{|c|c|c|c|c|}
\hline \multicolumn{5}{|c|}{ kinerja } \\
\hline Model & $\mathrm{R}$ & $R$ Square & $\begin{array}{l}\text { Adjusted } R \\
\text { Square }\end{array}$ & Std. Error of the Estimate \\
\hline 1 & $.784^{\mathrm{a}}$ & .614 & .576 & 1.95439 \\
\hline
\end{tabular}

Hasil pengolahan data, 2021

Besarnya Tabel 10. diatas diperoleh nilai Rsquare $\left(\mathrm{r}^{2}\right)$ sebesar 0.614 . Nilai tersebut mempunyai maksud bahwa pengaruh kepemimpinan, budaya organisasi dan disiplin kerja terhadap kinerja pegawai di Badan Kepegawaian Daerah Kabupaten Labuhanbatu Selatan sebesar $61.40 \%$, sedangkan sisanya sebesar $38.60 \%$ dipengaruhi oleh faktor-faktor lain yang tidak diteliti. Dengan kata lain variabel kinerja pegawai di Badan Kepegawaian Daerah Kabupaten Labuhanbatu Selatan dapat diterangkan oleh variabel kepemimpinan, budaya organisasi dan disiplin kerja sebesar $61.40 \%$, sedangkan sisanya sebesar $38.60 \%$ disebabkan oleh variabelvariabel lain yang tidak diteliti seperti fasilitas kerja, sikap kerja, motivasi kerja dan lain sebagainya.

\section{Evaluasi Data}

\subsection{Pengaruh Kepemimpinan Terhadap Kinerja Pegawai di Badan Kepegawaian Daerah Kabupaten Labuhanbatu Selatan.}

Berdasarkan pada hasil penelitian dapat dijelaskan bahwa kepemimpinan berpengaruh positif dan signifikan terhadap kinerja pegawai di Badan Kepegawaian Daerah Kabupaten Labuhanbatu Selatan. Hasil penelitian ini sejalan dengan hasil penelitian terdahulu dari Fauzi (2013), Osabiya Babatunde, Ikenga Emem (2015), Sami'an dan Estu Aprilian N.W, (2013) kesemuanya menyatakan bahwa kepemimpinan berpengaruh positif dan signifikan terhadap kinerja. Akan tetapi hasil penelitian bertentangan dengan hasil penelitian terdahulu dari Rahayu Saputri, Nur Rahmah Andayani, (2018), yang membuat kesimpulan bahwa kepemimpinan berpengaruh negatif dan tidak signifikan terhadap kinerja. Dari hasil penelitian ini dapat dijelaskan bahwa kepemimpinan pegawai di Badan Kepegawaian Daerah Kabupaten Labuhanbatu Selatan secara keseluruhan pada saat ini dalam kategori baik dan dapat meningkatkan kinerja pegawai.

\subsection{Pengaruh Budaya Organisasi Terhadap Kinerja Pegawai di Badan Kepegawaian Daerah Kabupaten Labuhanbatu Selatan.}

Berdasarkan pada hasil penelitian dapat dijelaskan bahwa budaya organisasi berpengaruh positif dan signifikan terhadap kinerja pegawai di Badan Kepegawaian Daerah Kabupaten Labuhanbatu Selatan. Hasil penelitian ini sejalan dengan hasil penelitian terdahulu dari Arifudin et.al (2018), Jatilaksono (2016), Maskur, (2010), Muchtar Adama (2014), Pranoto (2014), Soepardjo et.al (2014), kesemuanya menyatakan bahwa budaya organisasi berpengaruh positif dan signifikan terhadap kinerja. Akan tetapi hasil penelitian bertentangan dengan hasil penelitian terdahulu dari Wulan Sari Girsang (2019) yang membuat kesimpulan bahwa budaya organisasi berpengaruh negatif dan tidak signifikan terhadap kinerja. Dari hasil penelitian ini dapat dijelaskan bahwa budaya organisasi yang tercipta di Badan Kepegawaian Daerah Kabupaten Labuhanbatu Selatan secara keseluruhan pada saat ini dalam kategori baik dan dapat meningkatkan kinerja pegawai.

\subsection{Pengaruh Disiplin Kerja Terhadap Kinerja Pegawai di Badan Kepegawaian Daerah Kabupaten Labuhanbatu Selatan.}

Berdasarkan pada hasil penelitian dapat dijelaskan bahwa disiplin kerja berpengaruh positif dan signifikan terhadap kinerja pegawai di Badan Kepegawaian Daerah Kabupaten Labuhanbatu Selatan. Hasil penelitian ini sejalan dengan hasil penelitian terdahulu dari Dedi Hadian (2018); Flavia et.al (2017); Muhd. Darwis Damir (2016); Regina Aditya Reza (2010); dan Sarwani (2017), kesemuanya menyatakan bahwa disiplin kerja berpengaruh positif dan signifikan terhadap kinerja. Dari hasil penelitian ini dapat dijelaskan bahwa disiplin kerja pegawai di Badan Kepegawaian Daerah Kabupaten Labuhanbatu Selatan secara keseluruhan pada saat ini dalam kategori baik dan dapat meningkatkan kinerja pegawai. 


\subsection{Pengaruh Kepemimpinan, Budaya Organisasi Organisasi dan Disiplin Terhadap Kinerja Pegawai Di Badan Kepegawaian Daerah Kabupaten Labuhanbatu Selatan.}

Berdasarkan pada hasil penelitian dapat dijelaskan bahwa kepemimpinan, budaya organisasi dan disiplin berpengaruh positif dan signifikan terhadap kinerja pegawai di Badan Kepegawaian Daerah Kabupaten Labuhanbatu Selatan. Dari hasil penelitian ini dapat dijelaskan bahwa kepemimpinan, budaya organisasi dan disiplin secara bersama-sama di Badan Kepegawaian Daerah Kabupaten Labuhanbatu Selatan pada saat ini dalam kategori baik dan dapat meningkatkan kinerja pegawai.

\section{Kesimpulan}

1) Kepemimpinan berpengaruh positif dan signifikan terhadap kinerja pegawai Badan Kepegawaian Daerah Kabupaten Labuhanbatu Selatan.

2) Budaya organisasi berpengaruh positif dan signifikan terhadap kinerja pegawai Badan Kepegawaian Daerah Kabupaten Labuhanbatu Selatan.

3) Disiplin kerja berpengaruh positif dan signifikan terhadap kinerja pegawai Badan Kepegawaian Daerah Kabupaten Labuhanbatu Selatan.

4) Kepemimpinan, budaya organisasi dan disiplin kerja berpengaruh positif dan signifikan terhadap kinerja pegawai Badan Kepegawaian Daerah Kabupaten Labuhanbatu Selatan.

\section{DAFTAR PUSTAKA}

\section{Buku :}

AA. Anwar Prabu Mangkunegara, (2013), Manajemen Sumber Daya Manusia Perusahaan, Remaja Rosda Karya, Bandung

Abi Sujak (2010), Kepemimpinan Manajemen, Eksistensinya Dalam Perilaku Organisasi, Rajawali Pers, Jakarta

Barker, Alan (2012), Mengelola Sumber Daya Manusia, PT. Gramedia, Jakarta.

Dessler, Garry (2015), Manajemen Sumber Daya Manusia, PT. Preshelindo, Jakarta.

Edy Sutrisno, (2012), Manajemen Sumber Daya Manusia,Kencana Pernada Media Group

Edi Suharto (2009), Membangun Masyarakat Memberdayakan Rakyat, (Bandung: PT Rafika Aditama
Fahmi, Irham (2016), Manajemen Sumber Daya Manusia, Teori dan Aplikasinya.Bandung : Alfabeta

Ginandjar Kartasasmitha (2016), Pembangunan Untuk Rakyat: Memadukan Pertumbuhan dan Pemerataan, (Jakarta: PT Pusaka Cisendo

Gomez-Mejia, Balkin, dan Cardy, (2011), Managing Human Resources, International Edition. Prentice Hall International, Inc

Handoko (2013), Manajemen, Edisi Kedua, Cetakan Ketigabelas, BPFEYogyakarta.

Hasibuan, Malayu S.P, (2011), Manajemen Sumber Daya Manusia, Bumi Aksara, Jakarta.

Mangkunegara AP, (2015), Perencanaan dan Pengembangan Sumber Daya Manusia, Rfika Aditama, Bandung

Mangkuprawira, Sjafri, (2012), Manajemen Sumber Daya Manusia. Strategik, Ghalia Indonesia,Jakarta.

Rivai, Veithzal dan Sagala, Ella Jauvani. (2014). Manajemen Sumber Daya Manusia Untuk Perusahaan : Dari Teori ke Praktek. Jakarta : PT. Rajagrafindo Persada

Robbins Stephen, (2015), Perilaku Organisasi, Penerbit Salemba Empat, Jakarta

Robbins, P.Stephen dan Timothy A. Judge (2012), Perilaku Organisasi. Salemba Empat. Jakarta

Rush Michel, Althoff, Phillip (2015). Pengantar Sosiologi Politik. Jakarta : PT Raja Grafindo Persada

Samsudin, Sadili. (2012). Manajemen Sumber Daya Manusia. Bandung, CV. Pustaka Setia

Santoso, Singgih (20124), SPSS Statistik Parametrik, PT. Alex Media Komputindo, Kelompok Gramedia Jakarta.

Sedarmayanti (2017), Perencanaan dan Pengembangan Sumber Daya Manusia, PT Refika Aditama, Bandung

Siagian, Sondang. (2014). Manajemen Sumber Daya Manusia (cetakan 15). Jakarta: Bumi Aksara

Sudaryono (2017), Pengantar Manajemen : Teori dan Kasus, Pernerbit CAPS, Yogyakarta

Sugiyono. (2012). Metode Penelitian Kuantitatif dan Kualitatif dan R \& D. Bandung : Alfabeta

Yukl, G. (2013), Kepemimpinan Dalam Organisasi, Edisi Indonesia (kelima), Cetakan kedua, Jakarat Penerbit PT Indeks. 


\section{Jurnal :}

Agus Marimin (2011), Pengaruh gaya kepemimpinan, motivasi kerja, dan budaya organisasi terhadap kinerja karyawan pada Bank Muamalat Indonesia Cabang Surakarta, Jurnal Manajemen dan Bisnis Sriwijaya Vol.3 No.16

Ali, A.Y.S., Dahie, A.M., dan Ali, A.A. (2016). Teacher Motivation and Leadership, the Mediating Effect of Job Performance: Survey from Secondary Schools in Mogadishu. International Journal of Education and Social Science Vol. 3 No. 1. January 2016

Arifudin Aldisa, Brasit Nursin dan Dian Parawansa (2018), Pengaruh Pemberdayaan dan Budaya Organisasi Terhadap Kepuasan Kerja Serta Dampaknya Terhadap Kinerja Pegawai Dinas Perhubungan Kabupaten Merauke, Hasanuddin Journal of Applied Business and Entrepreurship, Vol 1, No. 3.

Firda Nova Manullang (2011), Pengaruh Pengawasan Dan Disiplin Terhadap Tingkat Kinerja Karyawan (Study Kasus Pada PT. Putra Jaya Sentosa Pekanbaru), https://media.neliti.com/media/publications/ 31181-ID

Flavia Reva Noel, S.L.H.V.Joyce Lapian, Merinda Pandowo (2017), The affect of work discipline and competence on employee performance (Case Study at Balai Kesehatan Mata Masyarakat Sulawesi Utara), Jurnal EMBA, VOL. 5 NO. 3 (2017).

https://ejournal.unsrat.ac.id/index.php/em $\mathrm{ba} /$ article/view/17613

I Putu Magna Anuraga, Desak Ketut Sinta Asih dan I Gede Riana (2017), Pengaruh
Kepemimpinan dan Pemberdayaan Terhadap Motivasi dan Kinerja Pegawai Dinas Pendidikan Pemuda dan Olah Raga Kabupaten Tabanandengan, E-Jurnal Ekobis Universitas Udayana 6.9 (2017) :3291-3324. Muchtar Adama (2014), Analisis Pengaruh Budaya Organisasi,Disiplin Kerja Serta Semangat Kerja Terhadap Kinerja Pegawai, (Studi Pada Kantor Dinas Pendidikan Kabupaten Sragen Bagian Subag Umum, Subag Keuangan, Subag PEP, Dikmen dan PNF Orseni, FE. UNDIP, Semarang.

Sami'an dan Estu Aprilian N.W, (2013), Pengaruh Kepemimpinan Dan Pengawasan Terhadap Kinerja Karyawan PT. Kereta Api Indonesia (Persero) Di Kantor DAOP IV Semarang, Jurnal Pendidikan Ilmu Sosial, Vol. 23, No. 1

A. Susi Hendriani, Yuli Artati (2014), Pengaruh Kepemimpinan, Budaya Organisasi dan Disiplin Kerja terhadap Kinerja Aparatur Sekretariat Daerah Kabupaten Kampar, Jurnal Pendidikan Ekonomi dan Bisnis/ Pekbis Jurnal, Vol.6, No.1, Maret 2014: 1425

Wulan Sari Girsang (2019), Pengaruh Budaya Organisasi dan Komitmen Terhadap Kinerja Karyawan RS Putri Hijau Medan, AJIE Asian Journal of Innovation and Entrepreneurship (e-ISSN: 2477- 0574 ; pISSN: 2477-3824) Vol. 04, Issue. 02, May 2019. 